\title{
The Economic Impact of COVID-19 from a Global Perspective
}

\author{
Alam Khan', Nadeem Khan', and Muhammad Shafiq ${ }^{2}$
}

ABSTRACT

\begin{abstract}
The world has been waging a fight against the novel coronavirus (COVID-19) since December 2019. The current coronavirus crisis is a catastrophe affecting billions of families worldwide. So far, COVID-19 has wreaked havoc across the globe: by slowing down economic growth; decreasing global trade; hurting health sector; increasing unemployment and underemployment; reducing FDI and hurting the tourism sector. This study investigates the economic costs of COVID-19. By using descriptive analysis, this study shows that the major economic variables, such as economic growth, global trade, health sector, unemployment and underemployment, foreign direct investment and travel and tourism sector have significantly affected by COVID-19.
\end{abstract}

KEY WORDS: $\quad$ COVID-19, economic performance, global economy.

JEL Classification: R11.

'Department of Economics, Kohat University of Science \& Technology (KUST), Kohat, Khyber Pakhtunkhwa, Pakistan 2Institute Of Numerical Sciences, Kohat University of Science \& Technology (KUST), Kohat, Khyber Pakhtunkhwa, Pakistan

\section{Introduction}

The COVID-19 outbreak poses a significant threat for many countries. Although European countries, United States and United Kingdom are frequently experience due to the novel Coronavirus. Asian countries including China, Iran, India and Pakistan also suffered due to the novel. The most prominent costs of COVID-19 outbreak are deemed to be economic, social, political and psychological. COVID-19 leads to inevitable costs for the novel-targeted countries and neighbors.

COVID-19 has both tangible and intangible costs, which affect countries economy through different channels. The short-run costs of COVID-19 consist of immediate losses of human and physical capital; health problems of victims and processes of consumers and producers. The long-run costs of COVID-19 include distortion of different types of economic activity and decrease productivity. The

Correspondence concerning this article should be addressed to: Alam Khan, Department of Economics, Kohat University of Science \& Technology (KUST), Kohat, Khyber Pakhtunkhwa, Pakistan. E-mail:alameconomist85@gmail.com tangible costs of COVID-19 include decrease in national income, economic growth, global trade, national investment, foreign direct investment inflows and tourist's revenue; increases in unemployment, exports and inflation.

The intangible costs of COVID-19 include, reduced standard of living, increased emotional harm and increased level of stress. Intangible costs include individual well-being, which is measured by different specifications. Mitchel et al. (2005) define wellbeing as the difference between all sources of satisfaction and all sources of apprehension. Therefore, well-being may be defined in the context individual satisfaction, which could be affected by COVID-19.

This article focuses on the global impact of COVID-19 from economic perspectives at country level by constructing a link between COVID-19 and economic variables such as economic growth, global trade, health sector, unemployment and underemployment, FDI and travel and tourism sector. COVID-19 has been a persistent issue since December 2019. On March 11, 2020, the World Health Organization (WHO) announced that the outbreak is 
officially a pandemic. Findings so far shows that the outbreak could trim the world economic growth by at least $0.5 \%$ to $1.5 \%$. It has revealed that the outbreak has inversely impacting the world economy. Moreover, estimates also indicates that full impact will not be known until the effects peak. So, this article tries to explore association of COVID-19 with the major economic variables.

\section{Lessons from the Past Epidemics}

In the past, the world has experienced several epidemics, including: The Great Influenza of 19181920, Severe Acute Respiratory Syndromes (SARS) in 2003, Avian Influenza (H5N1) of 2004-2006, Middle East Respiratory Syndromes (MERS) of 2012, Influenza A Virus Subtype (H7N9) of 2013 and the most recent COVID-19. Epidemics such as Great Influenza, SARS, MERS and COVID-19 have caused huge negative impacts on the economy. This plague had changed the role of the working class, welfare distribution, capital accumulation and affected socio-political significantly, with shift from feudalism to centralized governments (Bell \& Lewis, 2005).

Table 1 summarizes the methodologies and findings of selected studies on the macroeconomic cost of past pandemics.

The Spanish Flu caused around 39 million fatalities in 43 countries, which are equivalent to the losses of the WWI and led to path to the WWII. It was found that the Flu had negative impact on GDP to be around 6-8\% overall (Barro et al., 2020), while Correia et al. (2020) estimated that this pandemic curtailed manufacturing activity by around $20 \%$.

The SARS episode of 2003 is considered as a "services market destroyer" because of social fear and reduction in social contact reduced labor demand and supplies specifically in the service sector between 20 and 70\% (Lionello, 2017). Moreover, the worldwide macroeconomic impact of SARS was estimated around USD 3-10 million per case or USD 30-100 billion globally (Smith, 2006). While, this outbreak also caused losses of USD 12.3-28.4 billion and decrease of 1\% in GDP in China and $0.5 \%$ decrease in GDP of Southeast Asia (MacKellar, 2007).
The Middle East respiratory syndrome coronavirus (MERS-CoV) was first diagnosed in King Saudi Arabia in 2012 among the patients with severe respiratory disease (Zaki et al., 2012). According to the WHO estimates, the total 2519 laboratory-confirmed cases of MERS from April 2012 to January 2020, including 866 related deaths (case-fatality ratio $34.3 \%$ ) were reported globally. Majority of these cases were reported from Saudi Arabia (2121 cases), resulting 788 deaths having case fatality-rate of $37.1 \%$ (WHO, 2020). In 2015, the MERS-CoV outbreak decreased the number of foreign tourists by $41 \%$ compared to the same month of the last year. This outbreak resulted in an estimated economic loss of $\$ 10$ billion in the tourism sector alone in South Korea which is expected to shrink $0.1 \%$ off the GDP growth rate in 2015 (Joo et al., 2019).

Recently, at the end of December 2019, the world faced a new virus called COVID-19. The disease originated from Wuhan city, the capital of China's Hubei province (Zhou et al., 2020; C. Huang et al., 2020; Zhu et al., 2020). By March 2020, this virus has spread to other regions in Europe, Asia, Africa, North America, South America and Oceana (JHU, 2020; Nature, 2020; Chan et al., 2020; Reuters staff, 2020a; Reuters staff 2020b; Rothe et al., 2020). As far as COVID-19 is concerned, the International Labor Organization (ILO) reported that around 25 million jobs could be lost globally, which could lose approximately US $\$ 220$ billion in developing countries (ILO, 2020).

Due to the lockdown enforcement and voluntary social distancing, tourism, travel, catering and leisure got affected critically. Foregone revenue of China was predicted as $75 \%$ and this would mean approximately $\$ 95$ billion loss in 2020 (Hoque et al., 2020).

On March 2, 2020, the Organization for Economic Cooperation and Development (OECD) forecasted the world economic growth would be lowered by $0.5 \%$ for 2020 from $2.9 \%$ to $2.4 \%$, if the economic effects of the outbreak peak in the first quarter of 2020s (see Table 2). On March 23, 2020, OECD Secretary General Angel Gurria stated that:

The sheer magnitude of the current shock introduces an unprecedented complexity to economic 
Table 1. Economic Losses from Past Epidemics

\begin{tabular}{|c|c|c|c|}
\hline Epidemic(s) & Global Fatalities & Studies & Economic Losses \\
\hline \multirow{4}{*}{$\begin{array}{l}\text { The Great Influenza, } \\
\text { 1918-1920 }\end{array}$} & Up to 39 & Barro et al., (2020) & 6 ppt lower GDP growth and 8 ppt lower \\
\hline & Million in 43 & & consumption growth overall \\
\hline & countries & Correia et al., (2020) & $\begin{array}{l}18 \% \text { fall in manufacturing activity per year; } \\
\text { prompter and more aggressive containment } \\
\text { helped cushion the impact }\end{array}$ \\
\hline & & Brainerd \& Siegler, (2003) & $\begin{array}{l}\text { Mortality significantly lowers growth over } \\
\text { following decade }\end{array}$ \\
\hline \multirow[t]{5}{*}{ SARS, 2003} & 774 & Hai et al., (2004) & 1-2 ppt lower GDP growth in China \\
\hline & & Lee and McKibbin (2004) & $0.1 \%$ loss in global GDP in 2003 \\
\hline & & Wishnick, (2010) & Asian states lost USD 12-18 billion \\
\hline & & Smith, (2006) & $\begin{array}{l}\text { Global macroeconomic impact of SARS } \\
\text { epidemic was estimated at around USD 3-10 } \\
\text { million per cases or } 30-100 \text { billion overall }\end{array}$ \\
\hline & & MacKellar, (2007) & $\begin{array}{l}\text { Caused losses of USD } 12.3-28.4 \text { billion and } \\
\text { an estimated decrease of } 1 \% \text { in GDP in China } \\
\text { and } 0.5 \% \text { decrease in GDP in Southeast Asia }\end{array}$ \\
\hline MERS, 2012 & 866 & Joo et al., (2019) & $\begin{array}{l}\text { Caused an economic loss of } \$ 10 \text { billion in } \\
\text { tourism sector in South Korea which is } \\
\text { expected to cut } 0.1 \% \text { off the GDP growth } \\
\text { rate in } 2015\end{array}$ \\
\hline
\end{tabular}

forecasting. The OECD Interim Economic Outlook, released on March 2, 2020, made a first attempt to take stock of the likely impact of COVID-19 on global growth, but it now looks like we have already moved well beyond even the more severe scenario envisaged then.... the pandemic has also set in motion a major economic crisis that will burden our societies for years to come (COVID-19, 2020).

The literature on the causes of recession is vast (see Bentolila et al., 2018; Jagannathan et al., 2013; Main \& Sufi, 2010; Stiglitz, 2010; Bezemer, 2011; Bagliano \& Morana, 2012; Gaiotti, 2013). However, the one caused by COVID-19 is unprecedented in modern history. The outbreak and spread of the Coronavirus caused a new type of recession which is different from the past triggers of recession. For example, the 1997's Asian debt crisis was triggered by the plunge in value of Thai baht in 1997 spread to many countries in the region, which caused economic recession and financial crisis in Asia (Radelet \& Sachs, 2000).
The 2008-2009 global financial crisis was caused by loose monetary policy which created a bubble, weak regulatory structures, subprime mortgages and high leverage in banking sector (Allen \& Carletti, 2010). The 2016 recession in Nigeria was triggered by deficit in balance of payment, an increase in the pump price of petrol, drop in the price of crude oil, adoption of flexible exchange regime, infrastructure weakness and pipeline vandals, unstable exchange rate (Olanrewaju et al., 2018). The 2010 recession in Greece was caused by improper economic policies, the structural weakness in Greece economy, shocks of 2008-2009 financial crisis and monetary policy flexibility as a member of Eurozone (Rady, 2012). In this study, we try to show the economic cost of COVID-19

The rest of the paper is organized as follows. The second section discusses the global spread of COVID-19. The third and fourth sections of this research work explore the impact of this 
Table 2. OECD Economic Outlook Forecast, March 2020

\begin{tabular}{|c|c|c|c|c|c|}
\hline \multicolumn{6}{|c|}{ Percent change in Real GDP Growth } \\
\hline & & 2019 & & & 2021 \\
\hline & I & II & III & IV & $\mathrm{V}$ \\
\hline & & $\begin{array}{c}\text { November Projections } \\
\text { (2019) }\end{array}$ & $\begin{array}{c}\text { Difference from } \\
\text { November } \\
\text { (I-II) }\end{array}$ & $\begin{array}{c}\text { November } \\
\text { Projections } \\
\text { (2020) }\end{array}$ & $\begin{array}{c}\text { Difference from } \\
\text { November }\end{array}$ \\
\hline World & 2.9 & 2.4 & -0.5 & 3.3 & 0.3 \\
\hline G20 & 3.1 & 2.7 & -0.5 & 3.5 & 0.2 \\
\hline Australia & 1.7 & 1.8 & -0.5 & 2.6 & 0.3 \\
\hline Canada & 1.6 & 1.3 & -0.3 & 1.9 & 0.2 \\
\hline Euro Area & 1.2 & 0.8 & -0.3 & 1.2 & 0.0 \\
\hline Germany & 0.6 & 0.3 & -0.1 & 0.9 & 0.0 \\
\hline France & 1.3 & 0.9 & -0.3 & 1.4 & 0.2 \\
\hline Italy & 0.2 & 0.0 & -0.4 & 0.5 & 0.0 \\
\hline Japan & 0.7 & 0.2 & -0.4 & 0.7 & 0.0 \\
\hline Korea & 2.0 & 2.0 & -0.3 & 2.3 & 0.0 \\
\hline Mexico & -0.1 & 0.7 & -0.5 & 1.4 & -0.2 \\
\hline Turkey & 0.9 & 2.7 & -0.3 & 3.3 & 0.1 \\
\hline U.K. & 1.4 & 0.8 & -0.2 & 0.8 & -0.4 \\
\hline U.S. & 2.3 & 1.9 & -0.1 & 2.1 & 0.1 \\
\hline Argentina & -2.7 & -2.0 & -0.3 & 0.7 & 0.0 \\
\hline Brazil & 1.1 & 1.7 & 0.0 & 1.8 & 0.0 \\
\hline China & 6.1 & 4.9 & -0.8 & 6.4 & 0.9 \\
\hline India & 4.9 & 5.1 & -1.1 & 5.6 & -0.8 \\
\hline Indonesia & 5.0 & 4.8 & -0.2 & 5.1 & 0.0 \\
\hline Russia & 1.0 & 1.2 & -0.4 & 1.3 & -0.1 \\
\hline Saudi Arabia & 0.0 & 1.4 & 0.0 & 1.9 & 0.5 \\
\hline South Africa & 0.3 & 0.6 & -0.6 & 1.0 & -0.3 \\
\hline
\end{tabular}

Source: OECD Interim Economic Assessment: Coronavirus: The World Economy at Risk, Organization for Economic Cooperation and Development. March 2, 2020, p. 2.

current pandemic on world trade and health sector respectively. The fifth and sixth section of the study explain the global unemployment and reduction in FDI due to the coronavirus. The penultimate part of the paper discusses the condition of global tourism in the current pandemic. The last part of the paper includes concluding remarks.

\section{The Spread of COVID-19}

Real-time data on the spread of COVID-19 pandemic is collected from World meter. The data indicates that the USA has the highest number of infected individuals, followed by Spain, Italy, UK, France and Germany as at 6th May 2020. The statistics are reported in Table 3.

Regional data on the spread of COVID-19 reported by World Health Organization (WHO) shows that Europe is the hardest-hit continent by the novel of coronavirus, which has killed 145602 people, as indicated in Table 4 . Moreover, this is approximately $60 \%$ of the total global death toll. 
Table 3. COVID-19 Statistics (as of 6th May 2020)

\begin{tabular}{lccc}
\hline Countries & Confirmed Cases (Total) & Confirmed Deaths (Total) & Recovered (Total) \\
\hline Global & 3744582 & 258882 & 1249184 \\
USA & 1238040 & 72284 & 200669 \\
Spain & 250561 & 25613 & 154718 \\
Italy & 213013 & 29315 & 85231 \\
UK & 194990 & 29427 & N/A \\
France & 170551 & 25531 & 52736 \\
Germany & 167007 & 6993 & 137400 \\
Russia & 165929 & 1537 & 21327 \\
Turkey & 129491 & 3520 & 73285 \\
Brazil & 115953 & 7958 & 48221 \\
Iran & 99970 & 6340 & 80475 \\
China & 82883 & 4633 & 77911 \\
Canada & 62046 & 4043 & 26993 \\
Peru & 51189 & 1444 & 15413 \\
Belgium & 50781 & 8339 & 12731 \\
India & 49436 & 1695 & 14183 \\
Netherlands & 41087 & 5168 & N/A \\
Ecuador & 31881 & 1569 & 3433 \\
Saudi Arabia & 30251 & 200 & 5431 \\
Switzerland & 30009 & 1795 & 25400 \\
\hline Source Writdon & & &
\end{tabular}

Source: Worldometer, 2020

\section{Impact on the Global Trade}

On April 8, 2020, World Trade Organization (WTO) forecasted global trade volumes are projected to decrease between $13 \%$ and $32 \%$ in 2020 as a result of the economic impact of coronavirus pandemic, as shown in Table 5. Moreover, the WTO concludes that the impact of COVID-19 on world trade volumes could exceed the drop in world trade during the height of 2008-09 financial crisis (WTO, 2020).

The statistics in Table 5 show that all the geographic regions will face a double-digit decrease in trade volumes, except for "other regions," which consists of the Middle East, Africa and the Commonwealth of Independent States. Asia and North America could experience the sharpest decrease in exports volume.

\section{Impact on Health Sector}

In many countries, most of the testing equipment are in private hospital. China had shut down, temporar- ily, all hospitals in the city of Wuhan due to the coronavirus outbreak. As the virus was spreading quickly, the Spanish government nationalized all private hospitals and healthcare providers. Iran's hospitals also struggled to cope with the COVID-19 pandemic. Singapore had sufficient healthcare facilities and workers to handle the growing number of coronavirus patients. Moreover, the Ministry of Health ( $\mathrm{MOH})$ in Singapore also advised all the doctors in public and private to immediately stop accepting new foreign patients who do not live in the country (Healthcare, 2020).

Since outbreak was discovered in China and lockdowns were imposed, that affected the pharmaceutical supply chain. Drug makers around the globe depend on ingredients made in Chinese factories. Approximately $60 \%$ of the global active pharmaceutical ingredients (API) were made in china before the pandemic, and COVID-19 caused severe supply problems as china shutdown majority of its factories including drug production factories. 
Table 4. World Region Situation in Numbers as of 26th March 2020 as of 10:00CEST, 5th May 2020

\begin{tabular}{lcccc}
\hline Region & Confirmed Cases & New Cases & Total Deaths & New Deaths \\
\hline Globally & 3517345 & 81454 & 243401 & 3797 \\
Africa & 32570 & 2036 & 1112 & 27 \\
Americas & 1477447 & 43691 & 79590 & 1763 \\
Eastern Mediterra- & 213376 & 7077 & 8115 & 144 \\
nean & 1566684 & & & 1615 \\
Europe & 72688 & 22539 & 145602 & 219 \\
South-East Asia & 153868 & 5015 & 2682 & 29 \\
Western Pacific & 1096 & 6287 & \\
\hline
\end{tabular}

Source: WHO 2020

Table 5. WTO Forecast: Merchandise Trade Volume and Real GDP 2018-2021

\begin{tabular}{|c|c|c|c|c|c|c|}
\hline \multicolumn{7}{|c|}{ Annual Percentage Change } \\
\hline & \multicolumn{2}{|c|}{ Annual Percentage Change } & \multicolumn{2}{|c|}{ Optimistic scenario } & \multicolumn{2}{|c|}{ Pessimistic Scenario } \\
\hline & 2018 & 2019 & 2020 & 2021 & 2020 & 2021 \\
\hline $\begin{array}{l}\text { Volume of world merchandise } \\
\text { trade }\end{array}$ & $2.9 \%$ & $-0.1 \%$ & $-12.9 \%$ & $21.3 \%$ & $-31.9 \%$ & $24.0 \%$ \\
\hline \multicolumn{7}{|l|}{ Exports } \\
\hline North America & 3.8 & 1.0 & -17.1 & 23.7 & -40.9 & 19.3 \\
\hline South and Central America & 0.1 & -2.2 & -12.9 & 18.6 & -31.3 & 14.3 \\
\hline Europe & 2.0 & 0.1 & -12.2 & 20.5 & -32.8 & 22.7 \\
\hline Asia & 3.7 & 0.9 & -13.5 & 24.9 & -36.2 & 36.1 \\
\hline Other Regions & 0.7 & -2.9 & -8.0 & 8.6 & -8.0 & 9.3 \\
\hline \multicolumn{7}{|l|}{ Imports } \\
\hline North America & 5.2 & -0.4 & -14.5 & 27.3 & -33.8 & 29.5 \\
\hline South and Central America & 5.3 & -2.1 & -22.2 & 23.2 & -43.8 & 19.5 \\
\hline Europe & 1.5 & 0.5 & -10.3 & 19.9 & -28.9 & 24.5 \\
\hline Asia & 4.9 & -0.6 & -11.8 & 23.1 & -31.5 & 25.1 \\
\hline Other regions & 0.3 & 1.5 & -10 & 13.6 & -22.6 & 18.0 \\
\hline Real GDP at market exchange rate & 2.9 & 2.3 & -2.5 & 7.4 & -8.8 & 5.9 \\
\hline North America & 2.8 & 2.2 & -3.3 & 7.2 & -9.0 & 5.1 \\
\hline South and Central America & 0.6 & 0.1 & -4.3 & 6.5 & -11 & 4.8 \\
\hline Europe & 2.1 & 1.3 & -3.5 & 6.6 & -10.8 & 5.4 \\
\hline Asia & 4.2 & 3.9 & -0.7 & 8.7 & -7.1 & 7.4 \\
\hline Other regions & 2.1 & 1.7 & -1.5 & 6.0 & -6.7 & 5.2 \\
\hline
\end{tabular}

Source: WHO 2020 


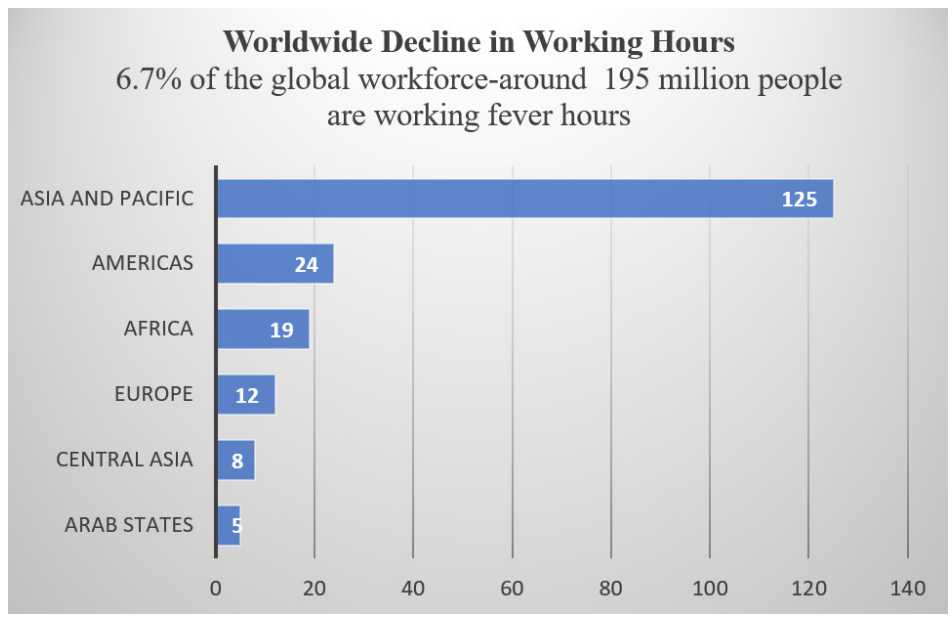

Figure 1. Worldwide decline in working hours.

Source: International Labour Organization

Note: the above figure the numbers are in million and full-time workers assuming a 48-hour working week.

\section{Impact on Global Unemployment and Underemployment}

The pandemic/health crisis has already transformed into economic, labor market crisis, impacting not only supply (production of goods and services) but also demand (consumption and investment). The pandemic crisis will have far reaching impacts on the labor market.

According to the International Labor Organization (ILO) statistics that globally unemployment and underemployment have been increased significantly due the pandemic. Based on different scenarios (see Annex I) for the impact of COVID-19 pandemic on the world GDP growth. Initial estimates of International Labor Organization (ILO) show an increase in the global unemployment between 5.3 million ("low" scenario) and 24.7 million ("high" scenario) from a base level of 188 million in 2019. The "mid" scenario suggests that an increase of 13 million (7.4 million in high-income countries). Through these estimates remain highly uncertain and all figures indicate a substantial increase in global unemployment.

According to the International Labor Organization (ILO), the coronavirus crisis wiped out $6.7 \%$ of working hours globally in the second quarter of 2020 . That is the equivalent of 195 million full-time workers losing their jobs. The Arab States is predicted to be the worst-hit region with an $8.1 \%$ decrease in working hours (5 million full time workers) followed by Central Asia with 8 million, Europe 12 million, Africa 19 million, Americas 24 million and Asia and pacific 125 million. The statistics are reported in Figure 1.

\section{Impact on Foreign Direct Investment}

The COVID-19 pandemic has created massive uncertainty in the global capital flows. By the day, projections of economic impact of the novel coronavirus are becoming more serious. According to the United Nation Conference on Trade and Development (UNCTD) the spread of COVID-19 will cause a dramatic decrease in foreign direct investment (FDI) flows across the world. In addition, the new estimates reported by UNCAD states that the outbreak and spread of COVID-19 could cut global $30 \%$ to $-40 \%$ during 2020-2021. Moreover, the report also shows that on average, the top 500 multinational enterprises (MNEs), which accounts for a significant share of FDI across the globe have now seen downward reversions of $30 \%$ to $40 \%$ for $2020-2021$ earnings estimates. 


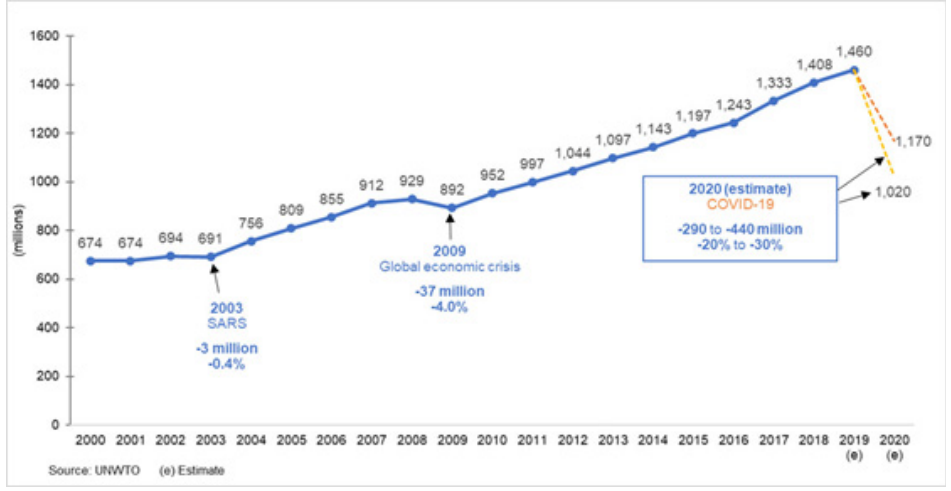

Figure 2. 2020 Forecast - international tourist arrivals, world (millions).

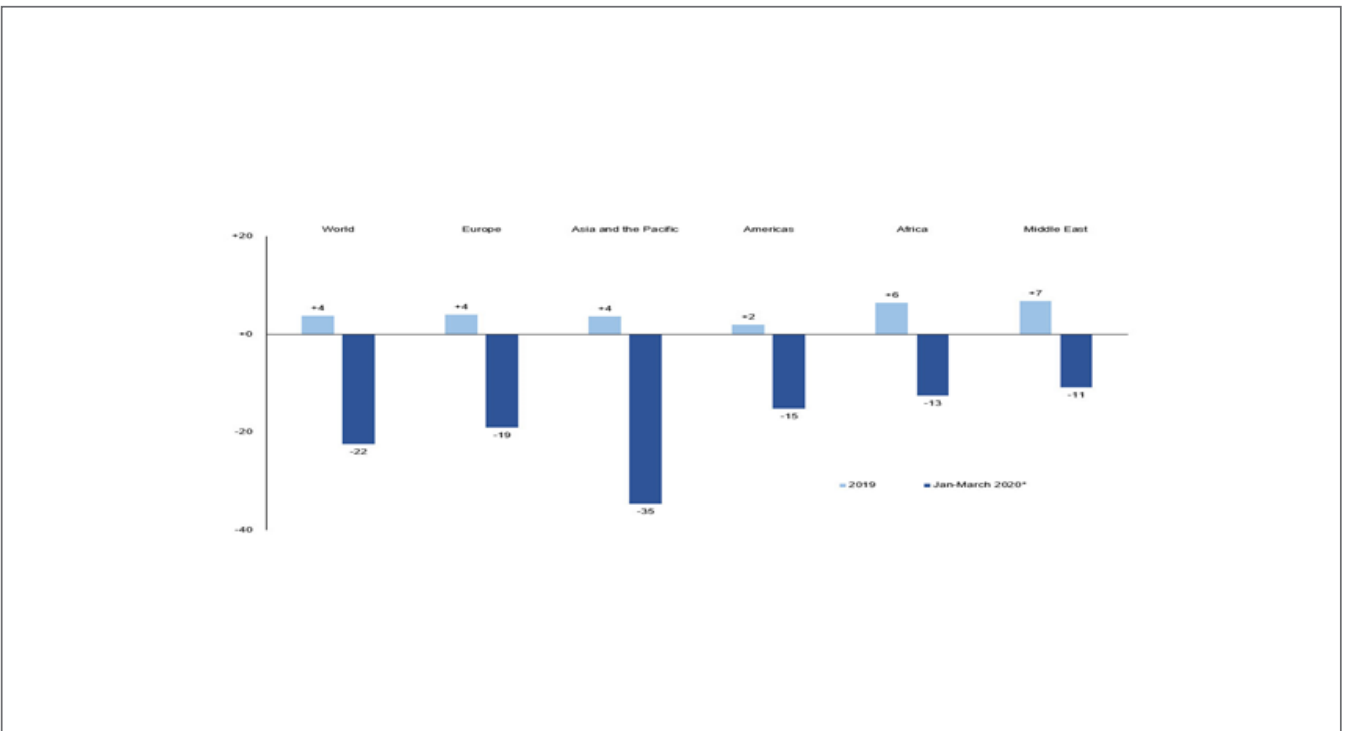

Figure 3. International tourist arrivals, 2019 and Q1 2020 (\% change). 


\section{Impact on the Travel and Tourism Sector}

The global Travel and Tourism sector experienced 3.5\% growth in 2019, contributing to the world economy growth of $2.5 \%$ for the ninth consecutive year. Moreover, this sector accounts US\$ 8.9 trillion contribution to the world GDP, 330 million jobs around the world, 10.3\% of global GDP, US\$ 948 billion capital investment (4.3\% of total global investment) and US\$ 1.7 trillion visitor exports.

The outbreak and spread of COVID-19 has brought the world to standstill with unforeseen and unparalleled impact on our economies, our lives, our livelihoods, and our societies. The tourism sector has been the worst affected of all major economic sectors. As of 27 March 2020, the estimates updated by the United Nation World Tourism Organization (UNWTO) reported that the international tourist arrival could decrease by $20 \%$ to $30 \%$ across the world during 2020 (see Figure 2).

The latest data from the United Nation World Tourism Organization (UNWTO) shows that the COVID-19 pandemic has caused a $22 \%$ decrease in international tourist arrivals during the first quarter of 2020. Moreover, the UNWTO also predicted that the COVID-19 crisis could lead to an annual decline of between $60 \%$ and $80 \%$ over the whole year when compared with the 2019 statistics. the estimates given in figure 2. Indicates that Asia and the Pacific are the worst affected regions so fat with -33 million arrivals, Europe is the second most affected region with -22 million arrivals. The statistics are shown in Figure 3.

\section{Conclusion}

The current pandemic of coronavirus has threatened the global economy. Almost all the countries of the world were affected. Some economies were severely affected by coronavirus as compared to other economies. As the impact of coronavirus can be seen more severe in Europe and America as compare to Asian economies. The COVID-19 has both tangible and intangible costs, which affect countries economy through different channels. The short-run costs of COVID-19 consist of immediate losses of human and physical capital; health problems of victims and processes of consumers and producers. The long-run costs of COVID-19 include distortion of different types of economic activity and decrease productivity. The tangible costs of COVID-19 include decrease in na- tional income, economic growth, global trade, national investment, foreign direct investment inflows and tourist's revenue; increases in unemployment, exports and inflation. The post coronavirus condition of the world would change the lifestyle of the global world. There may be more focus on health side a compare to the defense side.

In this situation the most important objective of the countries is to insure the financial support to the lower and middle class. In addition to these measures the businesses were also required to make them safe from bankruptcies. Furthermore, in some of advance countries like UK, Germany and Norway the VAT rebate are given to stimulate demand.

Due to this pandemic the challenge for the governments was how to reduce the debt ratios? For this purpose, many countries allowed debt to "erode" so that the nominal GDP growth rise more than the nominal debt, in a result it will decrease the share of public debt in the GDP. Although for some countries like, Italy and Japan, where the structural growth was not very much high will find difficulty to achieve the said goals. The other option is austerity measures through increase in taxes or/ and spending cuts, but it has been observed through the past that these measures didn't show the results in positive way.

Third option is to provisionally permit high inflation, which will lead to the increase in nominal growth and decrease in the debt simultaneously. Though some countries like Italy are not able to choose this option because of monetary policy with the ECB.

In most of the western world, it has been noted that it is very difficult to manage inflation regardless of very expansive monetary policies, inflation remained below the target in the last decade. In the current situation it is difficult to predict that how a country will choose the solution, but one cannot ignore the challenging reforms and tax increase nor be underestimated. In addition to flexible fiscal policy, incentives have been given to the industries and businesses for the survival in these crises. For these solutions large scale resources are required in medical, financial, fiscal, monetary and medical sides. In addition to these strategies are required for the developing world to involve both private and public sectors on urgent basis. In this context World Bank is working extensively to device such strategies to cope with the mentioned sectors to overcome the problems. 


\section{References}

Allen, F., \& Carletti, E. (2010). An overview of the crisis: Causes, consequences, and solutions. International Review of Finance, 10(1), 1-26. https:// doi.org/10.1111/j.1468-2443.2009.01103.x

Bagliano, F. C., \& Morana, C. (2012). The Great Recession: US dynamics and spillovers to the world economy. Journal of Banking \& Finance, 36(1), 1-13. https://doi.org/10.1016/j.jbankfin.2011.06.002

Barro, R., Ursúa, J. F., \& Weng, J. (2020). The Coronavirus and the Great Influenza Pandemic: Lessons from the "Spanish Flu" for the Coronavirus's potential effects on mortality and economic activity (Working Paper No. 26866). National Bureau of Economic Research. https://doi. org/10.3386/w26866

Bell, C., \& Lewis, M. (2005). Economic Implications of Epidemics Old and New. SSRN Electronic Journal.. https://doi.org/10.2139/ssrn.997387

Bentolila, S., Jansen, M., \& Jiménez, G. (2018). When credit dries up: Job losses in the great recession. Journal of the European Economic Association, 16(3), 650-695. https://doi.org/10.1093/ jeea/jvx021

Bezemer, D. J. (2011). The credit crisis and recession as a paradigm test. Journal of Economic Issues, 45(1), 1-18. https://doi.org/10.2753/JEI00213624450101

Brainerd, E., \& Siegler, M. (2003). The Economic Effects of the 1918 Influenza Epidemic . SSRN Electronic Journal. https://ssrn.com/abstract $=394606$

Chappell, B. (2020, March 11). Coronavirus: COVID-19 is now officially a pandemic, WHO says. National Public Radio. https://www.npr.org/ sections/goatsandsoda/2020/03/11/814474930/ coronavirus-covid-19-is-now-officially-a-pandemic-who-says

Chen, N., Zhou, M., Dong, X., Qu, J., Gong, F., Han, Y., ... \& Yu, T. (2020). Epidemiological and clinical characteristics of 99 cases of 2019 novel coronavirus pneumonia in Wuhan, China: A descriptive study. The Lancet, 395(10223), 507-513. https://doi.org/10.1016/S01406736(20)30211-7

Correia, S., \& Luck, S. (2020). Pandemics Depress the Economy, Public Health Interventions Do Not: Evidence from the 1918 Flu. SSRN Electronic Journal. https://doi.org/10.2139/ ssrn. 3561560
Gaiotti, E. (2013). Credit availability and investment: Lessons from the "great recession". European Economic Review, 59, 212-227. https://doi. org/10.1016/j.euroecorev.2012.12.007

Hai, W., Zhao, Z., Wang, J., \& Hou, Z. G. (2004). The short-term impact of SARS on the Chinese economy. Asian Economic Papers, 3(1), 57-61. https:// doi.org/10.1162/1535351041747905

Khalik, S. (2020, March 21). Coronavirus: Singapore has sufficient healthcare facilities. The Straits Times. https://www.straitstimes.com/singapore/ spore-has-sufficient-healthcare-facilities.

Hoque, A., Shikha, F. A., Hasanat, M. W., Arif, I., \& Hamid, A. B. A. (2020). The effect of Coronavirus (COVID-19) in the tourism industry in China. Asian Journal of Multidisciplinary Studies, 3(1), 52-58.

Huang, C., Wang, Y., Li, X., Ren, L., Zhao, J., Hu, Y., ... \& Cheng, Z. (2020). Clinical features of patients infected with 2019 novel coronavirus in Wuhan, China. The Lancet, 395(10223), 497-506. https:// doi.org/10.1016/S0140-6736(20)30183-5

Jagannathan, R., Kapoor, M., \& Schaumburg, E. (2013). Causes of the great recession of 2007 2009: The financial crisis was the symptom not the disease. Journal of Financial Intermediation, 22(1), 4-29. https://doi.org/10.1016/j. jfi.2012.06.002

Johns Hopkins, C. S. S. E. (2020). Coronavirus COVID-19 global cases by the center for systems science and engineering (CSSE) at Johns Hopkins University (JHU). Dipetik April, 15, 2020.

Joo, H., Maskery, B. A., Berro, A. D., Rotz, L. D., Lee, Y. K., \& Brown, C. M. (2019). Economic impact of the 2015 MERS outbreak on the Republic of Korea's tourism-related industries. Health security, 17(2), 100-108.

Intenrational Labour Organization. (2020, March 18). Almost 25 million jobs could be lost worldwide as a result of covid-19, says ILO: COVID-19: Protecting workers in the workplace [Press release]. https://www.ilo.org/global/about-the-ilo/ newsroom/news/WCMS_738742/lang--en/index.htm

Lee, J. W., \& McKibbin, W. J. (2004, April). Estimating the global economic costs of SARS. In K. Oberholtzer, L. Sivitz, A. Mack, S. Lemon, A. Mahmoud, \& S. Knobler (Eds.), Learning from SARS: preparing for the next disease outbreak: workshop summary (pp. 92-109).: National Academies Press. 
Lionello, L. (2017). Economics and epidemics: an historical analysis on the effects of infectuous diseases on economic development of four major outbreaks. [Bachelor's degree thesis]. LUISS Guido Carli. https://tesi.luiss.it/19837/

MacKellar, L. (2007). Pandemic influenza: A review. Population and Development Review, 33(3), 429-451. https://doi.org/10.1111/j.17284457.2007.00179.x

Mian, A., \& Sufi, A. (2010). The great recession: Lessons from microeconomic data. American Economic Review, 100(2), 51-56. https://doi. org/10.1257/aer.100.2.51

McKibbin, W., \& Fernando, R. (2020). The global macroeconomic impacts of COVID-19: Seven scenarios. Asian Economic Papers, 1-55. https:// doi.org/10.1162/asep_a_00796

Mitchell, A. J., Benito-León, J., González, J. M. M., \& Rivera-Navarro, J. (2005). Quality of life and its assessment in multiple sclerosis: Integrating physical and psychological components of wellbeing. The Lancet Neurology, 4(9), 556-566. https://doi.org/10.1016/S1474-4422(05)70166-6

Nature. (2020, April 22). Coronavirus: the first three months as it happened. Nature. https://www.nature.com/articles/d41586-020-00154-w

Olanrewaju, O. I., Idiake, J. E., \& Oyewobi, L. O. (2018). Global economic recession: Causes and rffects on Nigeria building construction industry. Journal of Surveying, Construction and Property, 9(1), 9-18.

Radelet, S., \& Sachs, J. (2000). The onset of the East Asian financial crisis. In J. Aziz, F. Caramazza, R. Salgado (Eds.), Currency crises (pp. 105-153). University of Chicago Press.

Rady, D. A. M. (2012). Greece debt crisis: Causes, implications and policy options. Academy of Accounting and Financial Studies Journal, 16, 87.

Reuters staff. (2020a, March 2). Algeria confirms two more coronavirus cases. Reuters. https:// www.reuters.com/article/idUKKBN20P016

Reuters staff. (2020b., March 2) Ecuador confirms five new cases of coronavirus, all close to initial patient. Reuters. https://www.reuters. com/article/us-china-health-ecuador-idUSKBN20O2EE

Rothe, C., Schunk, M., Sothmann, P., Bretzel, G., Froeschl, G., Wallrauch, C., ... \& Seilmaier, M. (2020). Transmission of 2019-nCoV infection from an asymptomatic contact in Germany. New England Journal of Medicine, 382(10), 970-971. https://doi.org/10.1056/NEJMc2001468
Smith, R. D. (2006). Responding to global infectious disease outbreaks: lessons from SARS on the role of risk perception, communication and management. Social science \& medicine, 63(12), 3113-3123.

Stiglitz, J. E. (2010). Interpreting the Causes of the Great Recession of 2008. Financial System and Macroeconomic Resilience: Revisited, 53, 297361.

Wishnick, E. (2010). Dilemmas of securitization and health risk management in the People's Republic of China: The cases of SARS and avian influenza. Health Policy and Planning, 25(6), 454466. https://doi.org/10.1093/heapol/czq065

World Health Organization. (2020). MERS situation update, January 2020. http://www.emro.who. int/health-topics/mers-cov/mers-outbreaks.html

World Health Organization. (2020). Coronavirus disease (COVID-19)

Situation report - 106. https://www.who.int/ docs/default-source/coronaviruse/situation-reports/20200505 covid-19-sitrep-106. pdf?sfvrsn=47090f63_2

Worldmeters. (2020). Reported cases and deaths by country or territory. https://www.worldometers. info/coronavirus/\#countries Retrieved 2020, August 20

World Trade Organization. (2020). https://www. wto.org/english/news_e/pres20_e/pr855_e.htm

Zaki, A. M. (2012). van BS, Bestebroer TM, Osterhaus AD, Fouchier RA. Isolation of a novel coronavirus from a man with pneumonia in Saudi Arabia. N Engl J Med, 367(19), 1814-20.

Zhou, P., \& Yang, X. (2020). L, Wang X-G, et al. A pneumonia outbreak associated with a new coronavirus of probable bat origin. $\mathrm{Na}$ ture, 579(7798), 270-273.

Zhu, N., Zhang, D., Wang, W., Li, X., Yang, B., Song, J., ... Tan, W. (2020). China Novel Coronavirus Investigating and Research Team. A novel coronavirus from patients with pneumonia in China, 2019. N Engl J Med, 382(8), 727-733. 


\section{Annex I: \\ Estimating the Impact of COVID-19 on World Work}

A number of scenarios can be explored to obtain a reasonable range for the unemployment impact of COVID-19 pandemic. The International Labor Organization (ILO) used the economic estimates in its modeling of the impact on labor market drawn from Mackibbin and Fernando (2020), who implements a range of demand and supply shocks in the world hybrid DSGE/CGE model. With the assumption that all countries will hurt from the virus during the course of the year. Moreover, their study suggest three different scenarios (low, mid, high) based on the strength of the effects of the pandemic. Using these scenarios the sets of estimates of unemployment are as follow. "Low" scenario where unemployment across the world would increase by 5.3 million, with an uncertainty ranging from 3.5 million and GDP growth decline by around $2 \%$. "Mid" scenario where unemployment across the globe would increase by 13 million (7.4 million in high income countries), with an uncertainty ranging from 7.7 to 18.3 million and GDP growth would fall by $4 \%$. "High" scenario where the pandemic has serios disruptive effects, where unemployment across the world would increase by 24.7 million, with an uncertainty of 13 to 36 million. 